\title{
Retail Business Health That Go Public in Indonesia Stock Exchange Enters the Era of Industrial Revolution 4.0
}

\author{
Basri Basri $^{1}$, Fery Kuswantara ${ }^{2}$ \\ Magister of Management Department \\ Janabadra University, Yogyakarta \\ Indonesia \\ basri@janabadra.ac.id, ferri@janabadra.ac.id
}

\author{
Fikri Budi Aulia ${ }^{3}$ \\ Department of Management, \\ Janabadra University, Yogyakarta \\ Indonesia \\ fikri.aulia@janabadra.ac.id
}

\begin{abstract}
This study aims to determine the potential for bankruptcy due to the ongoing industrial revolution 4.0 and the difference in potential bankruptcy of retail companies in Indonesia which are listed on the Indonesia Stock Exchange for the publication of financial statements for the 2016-2018 financial year. The research sample used was 14 companies with purposive judgment sampling method. The data collection technique uses the documentation method, namely data collection from the Indonesia Stock Exchange documents.

The data analysis technique used in this research is descriptive data analysis using the Altman Z-Score and Grover G-Score models.The criteria for company bankruptcy used the Altman method based on the $Z$-Score limit and with the criteria, if $Z<1.8$, the company is included in the bankrupt be careful, then if the $Z$ value>2.99 then the company is in the healthy category. category, if the $Z$ value $>1.81$ to $<2.99$ is included in the Gray Area category or situation.

Criteria based on Grover's G-Score, if the value of G $\leq \mathbf{- 0 . 0 2}$ then the company is included in the bankrupt category, and if the value of $G \geq 0.01$ then the company is included in the healthy category.

The results of this study indicate that there is a significant difference at the $\mathbf{5 \%}$ significance level, from the number of issuers that go bankrupt calculated by the Althman method and the Grover method. The results of the analysis using the Altman Z-Score method in 2016 showed that $39 \%$ of companies are in a healthy condition, $34 \%$ of companies are in a cautious condition, $27 \%$ of companies are in bankruptcy. In 2017, $46 \%$ of the companies were in a healthy condition, $27 \%$ of the companies were in a prudent condition, $27 \%$ of the companies were in bankruptcy. In $2018,45 \%$ of companies were in good health, $30 \%$ were in a prudent condition, and $25 \%$ were in bankruptcy. So the number of retail companies with the potential for bankruptcy decreased at the start of the industrial revolution 4.0 era.

The results of the analysis using the Grover method show that in 2016 there were $89 \%$ of companies in good health, and $11 \%$ of companies were in bankruptcy. In $2017,89 \%$ of companies were in good health, and $11 \%$ were in bankruptcy. In $2018,82 \%$ of the companies were in good health, and $18 \%$ of the companies were in bankruptcy. Based on the Grover method, it is found that an
\end{abstract}

increase in the number of retail companies that have the potential to go bankrupt.

Keywords: Company bankruptcy, industrial revolution era 4.0 Altman Z- Score Method, Grover G-Score Method

\section{INTRODUCTION}

The world in general, and Indonesia in particular, is entering a new industrial era marked by the era of digitization in various sectors of life. Experts call this the era of the industrial revolution 4.0 [1], [2], [3]. Changes in the dynamics of the rate of movement that were originally centralized that humans as vital subjects in the growth and development of the economic pulse have slowly but surely been replaced by mechanical automation and digitalization of technology in moving the wheels of the economy [4], [5], [6]. The development of automation innovation with the creation of super-computers, robotic artificial intelligence and genetic modification creates a world that is very different from the previous world [7], [8], [9]. According to [10] industry 4.0 is the name of the latest trend of automation and data exchange in factory technology, covering cyber- physical systems, the internet for all computing and cognitive computing characterized by the emergence of smart robots, artificial intelligence, the era of big data, the internet of things, the cloud. system, to technology-based companies. The implications of the industrial revolution have positive and negative values for the industry [5].

The retail business sector has fierce competition, there is also a change in consumer behavior who relies on online or e-commerce stores. The existence of this e- commerce affects the shopping habits of consumers because of the convenience it offers. As a negative impact, retail outlets were closed as an efficiency measure due to decreased sales [11].

The industrial and technological revolution has encouraged natural selection which leads to the strongest who wins the competition [12]. 
Business success according to [13] will be obtained if the products or services it sells are purchased by consumers from its competitors, and are sold at high prices to cover all costs and the wishes of the owner.

A company can win the business competition if it is able to produce products

/ services and services that are better than its competitors, while at the same time it is always able to adapt to any changes in the environment [12]. The negative impact of the industrial revolution 4.0 has the potential for bankruptcy of a company, so it is necessary to know early indications so that they can be anticipated before they occur. The method to detect the potential bankruptcy of a company can be used the Altman Z-Score [14] and also the Grover G-Score [15]. The Altman Z-Score method is a tool that calculates and combines certain financial ratios of the company in a discriminant equation which will produce a

certain score that will indicate the level of the possibility of company bankruptcy. Meanwhile, the Grover method is a model created by designing and reassessing the Altman Z-Score model.

Research [16] receipts Altman Z-Score models in predicting bankruptcy of PT. Ramayana Lestari Sentosa Tbk, PT. Matahari Putra Prima Tbk, and PT. Mitra Adiperkasa Tbk for the period 2013-2017, the results show that there is 1 company in the bankrupt category, namely PT. Matahari Putra Prima Tbk. Furthermore, research [17] analyzes mining and agricultural sector companies that are potentially bankrupt for the 2012-2015 data using the Grover method which shows that mining and agricultural sector companies are in a healthy condition. The results of [18] show that the Altman Z-Score model is appropriate to predict bankruptcy in go- public banking companies in Indonesia. he results of this study [19] indicate that the Grover Model is the most appropriate prediction model in predicting the financial distress of manufacturing companies in Indonesia. This study is to determine the potential bankruptcy of retail companies listed on the Indonesia Stock Exchange and to examine differences in bankruptcy predictions between the Altman ZScore and the Grover G-Score methods.

\section{METHOD}

A Population and Sample.

The population in this study amounted to 26 retail companies listed on the Indonesia Stock Exchange. In this study, sampling using the purposive judgment sampling method, namely taking samples that meet the criteria [20].(1 ). Retail companies listed on the Indonesia Stock Exchange for the period 2016-2018. (2) Retail companies that provide complete data. (3) A retail company that issues quarterly financial reports for 3 consecutive years. Based on the criteria, a research sample of 14 retail companies was obtained.

\section{Data collection technique}

The data used in this research is secondary data. The data obtained is quantitative data published by the Indonesia Stock Exchange, collected by document research method. Document research is conducted to obtain secondary data from the published Indonesia Stock Exchange. Documents as data sources in the form of retail company financial reports from www.idx.co.id from 2016 to 2018 .

Data Processing Techniques.

The data components needed from each published financial report are total assets, total liabilities, earning before tax, earning before interest and tax, earning after tax or net income, sales, current assets, current liabilities, retained earning, cash flow from operation., share price, number of shares outstanding and GNP index from the tribulation report. Then do the calculations. $\mathrm{X} 1$ is Working Capital To Total Assets, X3 is Earning Before Interest and Taxes to Total Assets, X4 = Market value of Equity Book Value of Liability, X5 $=$ Sales to Total Assets and X6 is Net Income on Assets. The Z-Score and G-Score calculations are performed based on the respective coefficients and variables. The score data is then analyzed for healthy, sick and bankrupt companies based on the cut off value of the Z-Scor and G-Scor. The data analysis method used consisted of descriptive statistics and data normality tests using SPSS version 19.00 for Window.

\section{Hypothesis Testing Techniques.}

Testing of each hypothesis is carried out using statistical tests in accordance with the research hypothesis that has been formulated. If the data is normally distributed, then this research hypothesis testing uses the independent sample t-test comparison analysis technique. This test is one type of average difference test, which tests whether there is a difference in the average between the two sample groups. Decision making in this test is based on a comparison of the probability value (Sig. 2- tailed), if the probability in this case is the value of Sig. 2-tailed $<0.05$ was significantly different. The next step is to test the accuracy of the predictions by calculating the level of accuracy for each model, namely the level of accuracy $=$ (number of correct predictions / number of samples) x $100 \%$.

\section{RESULTS AND DISCUSSION}

\section{A. Hypothesis.}

A successful company according to [13] that the company identifies, creates, and delivers a product or service that is highly valued by customers so that customers choose to buy from them rather than from their 
competitors, selling their product / service at a price high enough to cover costs. and compensate owners and creditors for the use of their money and their risks. From the financial aspect, the company is successful when it can maximize the value of the issuer. [13] shows that the indicators of a successful company are companies that have gone public and / or privatized which can maximize free cash flow and stock prices. Free cash flow is the net operating profit after tax after deducting net investment in operating capital.

The key to the success of the issuer in achieving the goal of value maximization according to [13] the company must have three things, namely: (1) having skilled people at all levels in the company, including leaders, managers, and a capable workforce. (2) have strong relationships with groups outside the company and (3) have sufficient funds to carry out their plans and support their operations. The key to success is not easy for a company to have due to changes in the macro environment that are difficult to predict. Likewise, in winning the competition, it must have a competitive advantage [12].

The industrial revolution 4.0 has a positive impact in the form of a capitalization effect, but it can also have a negative impact, namely the destruction effect. The positive and the disadvantages are being able to improve the quality of life, technology at hand, narrowing jobs, and the loss of privacy. For companies that cannot adapt to changes in the environment outside the company in the form of technological and digital advances, it can result in company bankruptcy. The factors causing the bankruptcy of a company according to [19] can come from internal factors such as weak human resource qualifications, lack of working capital, abuse of authority and fraud, as well as external factors in the form of intense business competition, reduced demand for products or services being sold, selling prices continuously, natural disasters that befall the company.

The bankruptcy of companies that go public according to [14] which is measured by 5 types of financial ratios that can be combined in a linear equation, namely Z- Score $=1.2 \mathrm{X} 1+1.4 \mathrm{X} 2+3.3$ $\mathrm{X} 3+0.6 \mathrm{X} 4)$

+0.999 (X5). The meaning of each $X$ in sequence, $\mathrm{X} 1$ is Working Capital To Total Assets, X2 is Retained Earning To Total Assets, X3 is Earning Before Interest \& Taxes to Total Assets, X4 is Market Value of Equity to Book Value of Debt and X5 is Sales To Total Assets. The cut off value is used from the $\mathrm{Z}$-Score, if the $\mathrm{Z}$ value $<1.8$ then the company is included in the bankrupt category, if the value is $1.81<\mathrm{Z}<2.99$ then the company is included in the careful category, and if the $\mathrm{Z}$ value $>2$, 99 then the company is included in the healthy category. Altman Model Revision The revision made by Altman is an adjustment made so that this bankruptcy prediction model is not only applied to companies that have not gone public.

Another model for predicting company bankruptcy from Grover [15] uses a sample according to the Altman Z-Score model, by adjusting the financial ratios the function is: $\mathrm{G}=$ $1,650 \mathrm{X} 1+3,404 \mathrm{X} 3-0.016 \mathrm{X} 6+$

0.05731. The meaning of each $\mathrm{X}$, that $\mathrm{X} 1$ is Working Capital To Total Assets, X3 is Earning Before Interest and Taxes to Total Assets, X4 = Market value of Equity Book Value of Liability, X5 $=$ Sales to Total Assets and X6 is Net Income On Assets. The cut off value is used from the G-Score, if the $G$ value $\leq-0.02$ then the company is included in the bankrupt category, if the $G$ value is $\geq 0.01$ then the company is included in the healthy category and if $\mathrm{G}>-0.02$ up to $\mathrm{G}<0.01$ is a sick company. Research [21] [22] [23] [24] found different prediction models in different industries. These models can be used for predictions with model specificities in each industry. Based on the reasoning in the literature review above, the hypothesis is formulated as follows:

H1: There are issuers that have gone bankrupt with the Altman model and Grover model predictions with different levels of prediction accuracy from the Altman model and the Grover model.

\section{B. Results and Discussion. Descriptive statistics.}

In this study, descriptive analysis was used to determine the minimum, maximum, mean and deviation of the bankruptcy rate of retail companies on the Indonesia Stock Exchange (BEI) in the tribunals during the 2016-2018 period. The minimum value describes the lowest value of a number of analyzed data. The maximum value describes the highest value from a number of analyzed data. The mean value describes the average score of the analyzed data. Standard deviation states the trend of variation in the analyzed data. Descriptive statistics are useful as a tool for analyzing data by describing the existing sample without making general conclusions. The results of the descriptive statistical test are presented in table III.1 below: 
Table III.1

Retail company Z-Score and G-Score value

\begin{tabular}{llrr} 
& & Z-Score & G-Score \\
\hline \multirow{2}{*}{$\mathrm{N}$} & Valid & 168 & 168 \\
\cline { 2 - 4 } & Missing & 0 & 0 \\
\hline Mean & 3.0877 & .5207 \\
\hline Median & 2.7200 & .4400 \\
\hline Std. Deviation & 2.05054 & .78440 \\
\hline Minimum & -2.60 & -2.93 \\
\hline Maximum & 8.92 & 1.96 \\
\hline
\end{tabular}

Source: The results of data processing

In table 1 , the highest $\mathrm{Z}$ score is 8.92 and the lowest is -2.60 with a mean of 3.0877 , which means that the average is healthy, but the distribution is quite wide with a standard deviation of 2.05054. The distribution during the 2016 to 2018 tribunals of those whose finances are healthy, sick and bankrupt is as shown in table III. 2 below:

Table III. 2

Criteria for Z- Score Companies

\begin{tabular}{|c|c|c|c|c|}
\hline \multirow{2}{*}{ Year } & \multirow{2}{*}{$\begin{array}{l}\text { Three } \\
\text { months }\end{array}$} & \multicolumn{3}{|c|}{ Company Criteria } \\
\hline & & Healthy & Disstress & Bankrupt \\
\hline \multirow{5}{*}{$\mathrm{C}^{\mathrm{OT}}$} & $T$ & $3=21 \%$ & $4=29 \%$ & $T=50 \%$ \\
\hline & II & $5=36 \%$ & $3=21 \%$ & $6=43 \%$ \\
\hline & III & $6=43 \%$ & $7=50 \%$ & $1=7 \%$ \\
\hline & IV & $8=57 \%$ & $5=36 \%$ & $1=7 \%$ \\
\hline & Amount & $22=39 \%$ & $19=34$ & $15=27 \%$ \\
\hline \multirow{5}{*}{$\begin{array}{l}201 \\
7\end{array}$} & $\mathrm{I}$ & $4=29 \%$ & $4=29 \%$ & $6=43 \%$ \\
\hline & II & $5=36 \%$ & $3=21 \%$ & $6=43 \%$ \\
\hline & III & $8=57 \%$ & $4=29 \%$ & $2=14 \%$ \\
\hline & IV & $9=64 \%$ & $4=29 \%$ & $1=7 \%$ \\
\hline & Amount & $26=46$ & $15=27$ & $15=27 \%$ \\
\hline \multirow{5}{*}{$\begin{array}{l}201 \\
8\end{array}$} & $\mathrm{I}$ & $4=29 \%$ & $4=29 \%$ & $6=43 \%$ \\
\hline & II & $6=43 \%$ & $4=29 \%$ & $4=29 \%$ \\
\hline & III & $7=50 \%$ & $4=29 \%$ & $3=21 \%$ \\
\hline & IV & $8=57 \%$ & $5=36 \%$ & $1=7 \%$ \\
\hline & Amount & $25=45 \%$ & $17=30 \%$ & $14=25 \%$ \\
\hline
\end{tabular}

Source: The results of data processing.

In table 1, the highest G-Score value is 1.96 and the lowest is -2.93 with a mean of 0.5207 , which means that the average is healthy, but the distribution is quite wide with a standard deviation of 0.78440 . The distribution during the tribunal from 2016 to 2018 for those whose finances are healthy and bankrupt is as shown in table III. 3 below:
Table III. 3

Criteria for G-Score Companies .

\begin{tabular}{|l|l|r|r|}
\hline \multirow{3}{*}{ Year } & \multirow{2}{*}{$\begin{array}{l}\text { Three } \\
\text { months }\end{array}$} & \multicolumn{2}{|c|}{$\begin{array}{c}\text { Company Criteria } \\
\text { G-Score }\end{array}$} \\
\cline { 2 - 4 } & & Healthy & Bankrupt \\
\hline 2016 & I & $12=86 \%$ & $2=14 \%$ \\
\cline { 2 - 4 } & II & $12=86$ & $2=14 \%$ \\
\cline { 2 - 4 } & III & $13=93$ & $1=7 \%$ \\
\cline { 2 - 4 } & IV & $13=93$ & $1=7 \%$ \\
\cline { 2 - 4 } & Amount & $50=89$ & $6=11 \%$ \\
\hline 2017 & I & $12=86$ & $2=14 \%$ \\
\cline { 2 - 4 } & II & $13=93$ & $1=7 \%$ \\
\cline { 2 - 4 } & III & $12=86$ & $2=14 \%$ \\
\cline { 2 - 4 } & IV & $13=93$ & $1=7 \%$ \\
\cline { 2 - 4 } & Amount & $50=89$ & $6=11 \%$ \\
\hline 2018 & I & $11=79$ & $3=21 \%$ \\
\cline { 2 - 4 } & II & $12=86$ & $2=14 \%$ \\
\cline { 2 - 4 } & III & $12=86$ & $2=14 \%$ \\
\cline { 2 - 4 } & IV & $11=79$ & $3=21 \%$ \\
\cline { 2 - 4 } & Amount & $46=82 \%$ & $10=18 \%$ \\
\hline
\end{tabular}

Source: The results of data processing Kolmogorov Smirnov Normality Test. In the data normality test, the One Sample Kolmogorov - Smirnov test was used by using a significance level of 0.05 , declared normally distributed if the significance was greater than 0.05 . The results of the normality test are shown in Table III.4 as follows :

\section{Table III.4}

NPar Test One-Sample Kolmogorov-Smirnoy Test Z-Score , G-Score

\begin{tabular}{llr|c}
\hline $\mathrm{N}$ & & 168 & 168 \\
\hline $\begin{array}{l}\text { Normal } \\
\text { Parameters }{ }^{\mathrm{a}, \mathrm{b}}\end{array}$ & Mean & 3.0877 & .5207 \\
\cline { 2 - 4 } & $\begin{array}{l}\text { Std. } \\
\text { Deviation }\end{array}$ & 2.05054 & .78440 \\
\hline $\begin{array}{l}\text { Most Extreme } \\
\text { Differences }\end{array}$ & Absolute & .101 & .141 \\
\cline { 2 - 4 } & Positive & .101 & .089 \\
\cline { 2 - 4 } & Negative & -.078 & -.141 \\
\hline Test Statistic & & .101 & .141 \\
\hline Asymp. Sig. (2-tailed) & $.000^{\mathrm{c}}$ & $.000^{\mathrm{c}}$ \\
\hline
\end{tabular}

Source: The results of data processing.

The results of the One Sample KolmogorovSmirnov test for a Z Scor value of 0.101> from 0.05 are significant, so the data is normally distributed, then for the G Scor the One Sample Kosmogorov- Smirnov test value 0.141> from 0.05 
means significant, then the data is normally distributed.

Hypothesis Testing Independent Sample T Tes. This hypothesis testing is conducted to determine whether there is a difference between the two paired dependent samples, namely whether there is a significant difference in predicting bankruptcy between the Altman prediction model and the Grover prediction model.

If the probability (in this case the Asymp. Sig. 2tailed value) $>0.05$, then there is no significant difference between the two sample groups, if the probability $<0.05$, then there is a significant difference between the two sample groups. Following are the results of the SPSS output on the independent sample $t$ test hypothesis testing are shown in Table III.5 as follows :

Table III. 5

Independent Samples Test

\begin{tabular}{|c|c|c|c|c|c|c|}
\hline \multicolumn{4}{|c|}{$\begin{array}{l}\text { Levene's Test for Equality of } \\
\text { Variances }\end{array}$} & \multicolumn{3}{|c|}{$\begin{array}{l}\text { t-test for Equality } \\
\text { of Means }\end{array}$} \\
\hline & & $\mathrm{F}$ & $\begin{array}{l}\text { Sig } \\
\mathrm{n}\end{array}$ & $\mathrm{t}$ & $\mathrm{df}$ & $\begin{array}{l}\text { Sig (2 } \\
\text { tailed } \\
)\end{array}$ \\
\hline \multirow{2}{*}{$\begin{array}{l}\text { Z- } \\
\text { Sc } \\
\text { or } \\
\text { e }\end{array}$} & $\begin{array}{l}\text { Equal } \\
\text { variances } \\
\text { assumed }\end{array}$ & $\begin{array}{l}92,3 \\
25\end{array}$ & .000 & $\begin{array}{l}15 \\
, 1 \\
55\end{array}$ & 334 & .000 \\
\hline & $\begin{array}{l}\text { Equal } \\
\text { variances } \\
\text { not } \\
\text { assumed }\end{array}$ & & & $\begin{array}{l}15 \\
.1 \\
55\end{array}$ & 214 & .000 \\
\hline
\end{tabular}

Source: The results of data processing.

The results of the analysis in Table 5 show the Sig. (2-tailed) between Altman and Grover's models is 0.000 , which means the probability $<0.05$, which means that there is a significant difference between the two sample groups, namely the $\mathrm{Z}$ Scor and the G Scor. From these results, it can be stated that $\mathrm{H} 1$ is accepted, there is a significant difference between the bankruptcy level of the $\mathrm{Z}$ Score and the $\mathrm{G}$ Score. with the accuracy level of the Altman model with a Z Score of $26.2 \%$ and the Grover model with a $G$ Score of $13.1 \%$.

The results of the analysis using the Altman ZScore method are in table 2, for 2016 there were $39 \%$ of companies in a healthy condition, $34 \%$ of companies were in a cautious condition, $27 \%$ of the companies were in bankruptcy. In $2017,46 \%$ of the companies were in a healthy condition, $27 \%$ of the companies were in a prudent condition, $27 \%$ of the companies were in bankruptcy. In $2018,45 \%$ of companies were in good health, $30 \%$ were in a prudent condition, and $25 \%$ were in bankruptcy. The results of the analysis using the Grover method show that in 2016 there were $89 \%$ of companies in good health, and $11 \%$ of companies were in bankruptcy.
In $2017,89 \%$ of companies were in good health, and $11 \%$ were in bankruptcy. In 2018 there were $82 \%$ of companies in good health, and $18 \%$ of companies were in bankruptcy. Based on the Grover method, it is found that an increase in the number of retail companies that have the potential to go bankrupt.

\section{CONCLUSION}

After analyzing the bankruptcy of the retail business that went public listed on the Indonesia Stock Exchange for the period 2016-2018, with the aim of testing whether there was a difference between the Altman and the Grover models, several conclusions were made, including: (1) There is a difference in the bankruptcy rate between the Altman model and the Grover model, with an accuracy rate of $26.2 \%$ of the Altman model and $13.1 \%$ of the Grover model. (2) The bankruptcy rate of the Altman model with the ZScore decreased in annual numbers, namely in 2016 by $27 \%$, still $27 \%$ in 2017 and $25 \%$ in the following year. Meanwhile, the Grover model with the G-Scor has increased, from 2016 by $11 \%$, to $11 \%$ in 2017 and $18 \%$ the following year. It is hoped that future studies can eliminate the limitations of this study, among others : (1) Adding more than two prediction models, namely the Springate and Zmijewski models. (2) It is also advisable to determine the time by taking into account capital market conditions. (3) Research on bankruptcy rates needs to pay attention to other factors such as stock prices.

\section{ACKNOWLEDGMENT}

Thanks for comments and suggestions from reviewers and audiences of The $3^{\text {nd }}$ International Conference on Banking, Accounting, Management and Economic (ICOBAME) 2020.

\section{REFERENCES}

[1] R. Nur and Muhammad, Opini Harian Republika: Menghadapi Era Disrupsi. Jakarta, 2017.

[2] S.-D. Cho, "The Ministry in the Age of the Fourth Industrial Revolution," Theol. Prax., vol. 61, pp. 621646, 2018.

[3] K. Chun, H. Kim, and K. Jang, "Analysis on Research Level of the Five Major Platform Technologies Related to the Fourth Industrial Revolution," 2017.

[4] Bekraf, "Kegiatan BEKRAF dan BPS Rilis Buku Statistik Ekonomi Kreatif," bekraf.go.id

[5] Badan Pusat Statistik, "Laporan Perekonomian Indonesia 2019," Lap. Perekon. Indones. 2019, vol. 04, no. 01, pp. 1-224, 2019

[6] B. Indonesia, Publikasi Laporan Perekonomian Indonesia. Bank Indonesia, 2018.

[7] L. F. de Souza Cardoso, F. C. M. Q. Mariano, and E. R. Zorzal, "A survey of industrial augmented reality," Comput. Ind. Eng., vol. 139, no. October 2019, p. 106159, 2020

[8] H. Panetto, M. Lezoche, J. E. H. Hormazabal, M. del Mar EvaAlemany Diaz, and J. Kacprzyk, "Special issue 
on Agri-Food 4.0 and digitalization in agriculture supply chains - New directions, challenges and applications," Comput. Ind., vol. 116, p. 103188, 2020.

[9] S. Doltsinis, P. Ferreira, M. M. Mabkhot, and N. Lohse, "A Decision Support System for rapid ramp-up of industry 4.0 enabled production systems," Comput. Ind., vol. 116, p. 103190, 2020

[10] Wikipedia. Industri 4.0. Ensiklopedia

Bebas.https://id.wikipedia.org/w/index.php?title=Indust ri_4.0\&oldid $=15385808.2019$

[11] Badan Pusat Statistik (BPS). 2010. Jumlah dan Distribusi Penduduk. Pertumbuhan Penjualan Emiten Ritel Turun.

[12] Stonehouse G and Snowdon B. Competitive advantage revisited Michael Porter on strategy and competitiveness," J. Manag. Inq. 2007.

[13] Ehrhard MC and Brigham EF. Financial Management, Theory and Practice, Thirteen Edition. South- Western USA, Cengange Learnimg.2013.

[14] Altman, Edward I. Financial Ratios, Discriminant Analysis and The Prediction of Corporate Bankcrupty. The Journal of Finance, 23(4), pp. 589-609. 1968.

]15] Hirawati, Heni. "Analisis Prediksi Financial Distress Berdasarkan Model Altman Dan Grover Pada Perusahaan Manufacktur Yang Terdaftar Di Bursa Efek Indonesia" Jurnal Riset Ekonomi Manajemen (Rekomen) Vol 2 (1). 2018.

[16] Rahmatullah, Muhammad dkk. "Analisis Laporan Keuangan dengan Model Z-Score sebagai Alat dalam Memprediksi Bankcruptcy (Studi Kasus pada PT. Ramayana Lestari Sentosa Tbk, PT. Matahari Putra Prima Tbk, dan PT. Mitra Adiperkasa Tbk)" Jurnal Riset Inspirasi Manajemen Dan Kewirausahaan Vol 3 (1), hal. 22- 29. 2019.

[17] Limanto, Michael Citra. "Analisis Prediksi Kebangkrutan Perusahaan Sektor Pertambangan Dan Pertanian
Menggunakan Metode Grover Tahun 2012- 2015" Arthavidya Jurnal Ilmiah Ekonomi Vol 19 (1), hal. 6376. 2017.

[18] Aminah dan Andi Sanjaya. "Analisis Kebangkrutan Pada Perusahaan Perbankan Di Indonesia Periode 2001-2012 (Dengan Menggunakan Model Altman Z-Score)" Jurnal Akuntansi \& Keuangan Vol 4 (2). 2013.

[19] Hery. 2017. Kajian Riset Akuntansi Mengulas Berbagai Hasil Penelitian Terkini dalam Bidang Akuntansi dan Keuangan. Jakarta: PT Grasindo.

[20] Cooper D.R, Emory C.W, Business Research Methods, Fith Edition. Richard D.Irwin Inc., 1995.

[21] Zakkiyah, Ufi Zuhriyatuz dkk. "Analisis Penggunaan Model Zmijewski (XScore) Dan Altman (Z-Score) Untuk Memprediksi Potensi Kebangkrutan (Studi Pada Perusahaan Tekstil Dan Garmen Yang Terdaftar Di (BEI) Bursa Efek Indonesia Periode 2009- 2012)" Jurnal Administrasi Bisnis Vol 12 (2). 2014.

[22] Rini Tri Hastuti. Analisis komparasi model prediksi financial distress Althman, Springate, Grover dan Ohlon pada Perusahaan Manufaktur yang terdaftar di Bursa Efek Indonesia periode 2014-2013. Jurnal Ekonomi/Volume XX, No. 03, November 2015: 446-462. 2015.

[23] Parquinda L dan Azizah DF.. Analisis Penggunaan Model Grover (G-Scor), Fulmer (H Score), Springate (S-Score), Zmijewski (X-Score) dan Altman (Z-Score) sebagai Prediktor Kebangkrutan (Studi pada Perusahaan Tekstil dan Garmen yang Listing di Bursa Efek Indonesia (BEI) Periode 2015-2017). Jurnal Administrasi Bisnis (JAB)|Vol. 72 No. 1 Juli 2019| 110-118. 2019

[24] Primasari NS. Analisis Altman Z Scor, Grover Scor, Springate dan Zmijewski sebagai Signaling Financial Distress (Studi Empiris Industri Barang-Barang Konsumsi di Indonesia) Journal Accounting and Management, Vol. 1, No. 1, July 2017. p 23-41.201 